\title{
Politeness Strategies Applied by the Characters of The Great Debaters Movie
}

\author{
Miwita Rosari \\ Sanata Dharma University \\ ariamiwitarosari@gmail.com
}

\begin{abstract}
This research explores politeness strategies used by the characters in The Great Debaters movie. The data used in this research were collected from 166 pages of The Great Debaters movie transcription. The analysis is based on Brown and Levinson's politeness strategies and Spolsky's factors affecting someone's politeness in speaking. The research results showed that the characters in The Great Debaters movie applied the types of politeness strategies, namely off-record, baldon-record, positive politeness, and negative politeness. Moreover, the characters also revealed the factors affecting the characters' politeness in speaking, namely language style, register and domain, and slang and solidarity. However, the characters did not show language and gender factor in their conversation since they were mostly engaged in the same topic, namely a debate competition.
\end{abstract}

Keywords: politeness strategies, character, The Great Debaters

\section{Introduction}

In daily conversations, language reflects the context in which it is used. Moreover, people will adapt their talk to suit the audience. People use language differently in formal and casual expressions. People in their relation to others need to preserve these kinds of expressions for themselves and people they interact with polite utterances. In social interaction, to be polite is very important in keeping the smoothness of the interaction. People need to see to whom they are speaking because some expressions may be considered rude. It is needed to identify the social values of a society in order to speak politely. The study of politeness strategy is basically the study of knowing the way people use a language while they are having interaction or communication. It gives the information on how to use a language and conduct smooth and flowing conversations. People who study other languages need to understand about other cultures because culture and language are inseparable.

The writer focuses on a movie entitled The Great Debaters, an American movie which is based on a true story. It tells about the efforts of 
an underdog debate team from Wiley College whose members are "black" people that want to place their team on equal footing with "whites". The writer chooses The Great Debaters movie because it serves a great deal of politeness phenomena among the characters in which writer seeks to analyze. The Great Debaters movie is an excellent source since it has various utterances which can be the main source and object to be analyzed. The writer focuses on the characters' utterances in the forms of social behavior involving language. The writer is impressed by various cultures in the world, in particular Indonesia and English culture in speaking politely. By considering the phenomena, the writer analyzes the politeness strategies used by the characters in The Great Debaters movie since it is interesting to reveal the different ways among the characters interaction by means of communication, especially in the use of politeness strategies and the factors affecting speaking politeness.

As communication plays an important role in keeping the smoothness of an interaction, there is a need to raise second language (L2) learners' consciousness in characteristically distinct features of two languages. One of the examples is the use of politeness strategies. Indonesian and English society may learn the concept of politeness from each other that is referred to as mutual respect. For example, Indonesian society can learn from English society about how one's attitude in keeping the eye contact, proper body language or sincere smile when speaking to others.

This research aims to answer two research questions: (1) Which types of politeness strategies are used by the characters in The Great Debaters movie? and (2) What factors affect the characters' politeness in speaking? The following briefly discuss the concepts of politeness, politeness strategies, and factors affecting someone's politeness in speaking which used as the basic theory to answer the two research questions.

\section{Theoretical Ground}

\section{Politeness}

Being polite is not a matter of saying "please" and "thank you" (Holmes, 1995, p. 296). A polite person makes others feel comfortable. Being linguistically polite involves speaking to people appropriately in the light of their relationship to others. The basic concept adopted in this research is politeness developed by Brown and Levinson (1987). They assume that each participant is endowed with what they call face, which is developed into negative face and positive face. According to Goffman (1967), face is the positive social value a person effectively claims for himself by the line others assume he has taken during a particular context. Face, in a sense, is one's situated identity but it is not a specific identity (e.g., sophisticated). Meanwhile, Brown and Levinson (1987) define face as the public selfimage that every member wants to 
claim for himself. One's negative face includes claims to freedom of an action and freedom from imposition. One's positive face involves the needs for social approval or the want to be considered desirable by at least some others.

Brown and Levinson (1987) define politeness as rational behavior aiming at the strategic softening of face threatening acts. A Face Threatening Act is a threat to a person's face. Face Threatening Acts, according to Brown and Levinson (1987) are acts that by their nature run contrary to the face wants of the intended hearer and/or of the speaker. It is in line with Yule (1996, p. 61) that FTAs are acts which threatens the positive or negative face of the hearer. The speaker, in some ways, threatens the self-image of the hearer. The acts are usually done verbally. For example, if someone asks to borrow money, he is potentially imposing on the person's and so threatening his negative face. Conversely, if someone's apologize to other, he will be threatening his positive face since he is acknowledging having imposed on the person and asking for acceptance of this.

\section{Politeness Strategies}

Since some acts are threatening to face and require softening, language users try to develop politeness strategies to reduce face loss. Brown and Levinson (1987, p. 92) categorize politeness into four (4) politeness strategies; Off Record, Bald-on Record, Positive, and
Negative Politeness. Each strategy will be presented as follows.

\section{Off Record}

According to Brown and Levinson (1987), off-record or indirect strategy is done to let speakers figure out the unclear communicative intention. It indicates if the speakers want to avoid their responsibility of doing face threatening acts, they can employ the strategy and let the hearers interpret the intended message. Off-record simply means the statement when one's saying is not directly addressed to the other or 'hints'. "Uh, I forgot my pen", means that the speaker wants the intended hearer to lend a pen. The meaning of the statement is not directly stated by the speaker and therefore the addressee needs to interpret the meaning. The following are the sub strategies of off record politeness strategy.

1) Strategy 1: Give hints

2) Strategy 2: Give association clues

3) Strategy 3: Presuppose

4) Strategy 4: Understate

5) Strategy 5: Overstate

6) Strategy 6: Use tautologies

7) Strategy 7: Use contradictions

8) Strategy 8: Be ironic

9) Strategy 9: Use metaphors

10) Strategy 10: Use rhetorical questions

11) Strategy 11: Be ambiguous

12) Strategy 12: Be vague

13) Strategy 13: Over-generalize

14) Strategy 14: Displace hearer

15) Strategy 15: Be incomplete, use ellipsis 


\section{Bald-on Record}

Brown and Levinson (1987) state that bald-on record is used in different situations since speakers can have different motives in doing the face threatening acts. This strategy is ranked as the most direct strategy. It refers to the expression of an act in the most direct way. It requires no effort from the speakers to reduce the impact of the FTAs. Bald-on-record is likely to shock people to be addressed, embarrass them, or make them feel a bit uncomfortable. "Come in" or "Do sit down" are the examples of bald onrecord. Moreover, the speaker can ask the hearer to do something, for example, "Pass me the ketchup!". The strategy can shock the hearer, therefore this type of strategy is commonly found in people who know each other very well and are very comfortable in their environment, such as close friends and family members. The following are the sub strategies of bald-on record politeness strategy.

1) Strategy 1: Great Urgency or Desperation

2) Strategy 2: Speaking as if great efficiency is necessary in attentiongetters

3) Strategy 3: Task-oriented or Paradigmatic Form of Instruction

4) Strategy 4: Sympathetic Advice or Warning

5) Strategy 5: Granting Permission for Something

6) Strategy 6: Invitations

7) Strategy 7: Welcoming

8) Strategy 8: Greetings and Farewells

\section{Positive Politeness}

Positive politeness confirms that the relationship of both speakers and hearers are friendly and expressing group reciprocity to minimize the distance among them. Brown and Levinson (1987) state that this strategy attempts to attend the hearers' interests, needs, wants, and goods. Positive politeness addresses the positive face wants of the interactants or desire of connection. In Brown and Levinson's view, positive politeness is assumed to be less polite than negative politeness. The important function of positive politeness is to share some degrees of familiarity with the hearer. It can be considered as the code or language of intimacy. This can be accomplished in various ways, for example, the use of joking and familiar terms of address. "Honey", "luv", and "sister" are the examples of the use familiar terms of address used in group identity makers. The following are the sub strategies of positive politeness strategy.

1) Strategy 1: Notice, attend to a hearer (her or his interests, wants, needs, goods)

2) Strategy 2: Exaggerate (interest, approval, sympathy with hearer)

3) Strategy 3: Intensify interest to a hearer; making good story, draw the hearer as a participant into the conversation.

4) Strategy 4: (Use in-group identity markers); address form, in-group language or dialect, jargon or slang, contraction and ellipsis. 
5) Strategy 5: Seek agreement; repetition - agreement may also be stressed by repeating part or all of what the preceding speaker has said

6) Strategy 6: (Avoid disagreement); token agreement, pseudo-agreement, white lies, hedging opinions.

7) Strategy 7: Presuppose/ raise/ assert common ground; gossip, small talk, point-of-view operations, presupposition manipulations.

8) Strategy 8: Joke

9) Strategy 9: Assert or presuppose speaker's knowledge of and concern for hearer's wants.

10) Strategy 10: Offer, Promise

11) Strategy 11: Be optimistic

12) Strategy 12: Include both a speaker and a hearer in the activity

13) Strategy 13: Give (or ask for) reasons

14) Strategy 14: Assume or assert reciprocity

15) Strategy 15: Give gifts to a hearer (goods, sympathy, understanding, cooperation)

\section{Negative Politeness}

On the other hand, Brown and Levinson (1987, p. 131) define negative politeness as "the heart of respect behavior" and it is "more specific and focused." The function of this strategy is to minimize imposition on the hearers. It aims at the realization of solidarity. Therefore, it automatically assumes that there might be some social distances or awkwardness in the situation. Using hedges or questions is one of the examples of negative politeness strategy. "I just want to ask you if I could use your pen?" is the example of minimizing imposition. The following are the sub strategies of negative politeness strategy.

1) Strategy 1: Be conventionally indirect

2) Strategy 2: Do not assume a hearer is able or willing to comply to any acts imposed on him.

3) Strategy 3: Be pessimistic about ability or willingness of a hearer to comply to any acts imposed on him.

4) Strategy 4: Minimize the imposition

5) Strategy 5: Give deference.

6) Strategy 6: Apologize; admit the impingement, indicate reluctance, give overwhelming reasons, beg forgiveness.

7) Strategy 7: Impersonalize a speaker and a hearer; per-formatives, impersonal verbs, address terms as 'you' avoidance.

8) Strategy 8: State the FTA as a general rule

9) Strategy 9: Nominalize to distance the actor and add formality 10) Strategy 10: Go on record as incurring a debt, or as not indebting a hearer.

\section{Factors Affecting Someone's Politeness}

Spolsky (1998) identifies four factors which affect people's politeness. There are language styles, registers and domains, slang and solidarity, and language and gender. Those four factors determine the use of language concerning politeness between speakers and hearers. The 
explanation for each factor is described as follows.

\section{Language Styles}

A speaker is usually aware of the hearer. People can choose to speak formally or informally according to the person they are addressing. According to Spolsky (1998), people can consciously choose how they try to use language by applying formal or informal expressions to people that they address. Further, he states that when one speaks formally, he is engaged in favored and educated norms of their society because he is able to use his language well. Thus, Spolsky (1998) also states the importance of language style is to represent the speaker's sense of identity.

Registers and Domains

Spolsky (1998) emphasizes that people with particular occupation may create terms for new concepts. People who work at mining environment will be different from people who work at geology in terms of language. Each group can develop terms which may not be familiar for people who do not keep up with the other environment. Thus, a register is a variety of language involving roles and statuses, which is used in certain situations. Social situation is also a key to determine politeness in speaking. Spolsky (1998) states that there is a typical domain which defines the way people speak in terms of social situation. Further, he states that domains are named usually for a place or an activity in it.
Two common domains are home and work.

Slang and Solidarity

Spolsky (1998) mentions that slang is used as special kinds of intimate or in-group speech. Slang has social functions as a sign of identity membership and solidarity among people who use it. Spolsky (1998), further, explains that solidarity has a major impact on language. People tend to show group solidarity to others by applying the same language use, such as accent or word choice.

The importance of language in establishing social identity is also shown in the case of slang. Slang is a kind of jargon marked by its rejection of formal rules and its marked use to claim solidarity. Slang regularly transgresses other social norms, making free use of taboo expressions. The use words like 'fuck' and 'shit' in public media has become a sign of revolt, depending on one's point of view.

\section{Language and Gender}

Spolsky (1998) states that both men and women share differences in vocabulary. As for children, they tend to pick women's and men's talk as social stereotypes. They assume women's talk has something to do with home and domestic activities, whereas men's talk is associated with the outside world and economic activities.

\section{Method}


The writer conducted this research which was categorized as qualitative research. Frankel and Wallen (2006) state that qualitative research is a study which investigates the quality of relationship, activities, situations, and materials. Besides, the data collected are in the forms of descriptive rather than numerical or statistical data. Therefore, this study do not deal with any numerical data. It refers to Sutopo's theory that in qualitative research, the data collected are usually in the forms of words, sentences or pictures in which the meaning is more significant than number (2002, p. 35).

In conducting qualitative research, there are several methods that can be applied. Some of them are content analysis, case study, and discourse analysis. The writer used discourse analysis as the method in accomplishing this research. Taylor (2001) loosely defines discourse analysis as "the close study of language in use". Primarily, Potter and Wetherell (2001) state discourse analysis espouse the principle that people construct versions of their social world through the instrumentality and functionality of language.

Discourse analysis is more concerned with the analysis of texts and/or utterances within specific socio-cultural context and indicates a method of data analysis that can tell researchers about the discursive construction of a phenomenon (Willig, 2008). Specifically, this method focuses on a power, domination and construction, and reproduction of power in texts and conversations, language in social contexts, and interactions (Cohen, Manion, \& Morrison, 2011). The use of discourse analysis for this research was due to the focus of this study which was analyzing the types of politeness strategies and the factors affecting someone in speaking politeness. Since this study dealt with language use in social interactions, discourse analysis was considered as the most appropriate method for this study.

Having analyzed the transcription, the writer categorized the characters' utterances into four potential types of politeness strategies proposed by Brown and Levinson (1987). Each utterance in the movie's script was put into each category to help the writer in analyzing the data. After categorizing the characters' utterances, the writer identified each utterance to find the factors affecting the characters' politeness in speaking. The writer employed the theory proposed by Spolsky (1998) related to politeness factors in speaking. Then, the writer provided explanations on each character's utterances presented as the examples and associated the findings.

\section{Findings And Discussion}

\section{Politeness Strategies Used in The Great Debaters Movie}

Since some acts are threatening to face and require softening, language users try to develop politeness strategies to reduce face 
loss. Brown and Levinson (1987) categorize politeness into four types that sum up human politeness behavior: off-record, bald-on-record, positive politeness, and negative politeness. In the discussion below, the writer found that the six characters of The Great Debaters movie revealed the four types of politeness strategies proposed by Brown and Levinson (1987). The following analyses of the four types of politeness strategies were arranged based on the frequency of occurrence.

\section{Positive Politeness}

The positive politeness strategy was the most dominant strategy found in the movie. The characters in The Great Debaters movie revealed the subtypes of positive politeness strategy, i.e. including both a speaker and a hearer in the activity, being optimistic, noticing hearer's needs and wants, seeking agreement, using in-group identity markers, promising, asking for reasons, presupposing speaker's knowledge, exaggerating, and drawing hearer as the participant into the conversation. The results and discussion of positive politeness strategy were as follows.

Dialogue 1

Henry : What's going on?

James : We're gonna go get Mr. Tolson and Samantha, head back to the campus, and have a pep rally.

(J/ PP/01:05:23,499)

Samantha decided to sleep in Henry's house. In the next morning, James and the school band came to
Henry's house. Suddenly, James knocked the door. He asked Henry to get ready and go with him. Henry and Samantha were very shocked.

The conversation above showed that James revealed positive politeness strategy, i.e. including both a speaker and a hearer in the activity. In this case, James used the word we which meant he included Henry, the hearer, as a participant in his utterance. Brown and Levinson (1987) assert a speaker is done this strategy by using we form when he or she really means you or me to address a hearer. This subtype of positive politeness strategy had the higher frequency than the others subtypes.

Dialogue 2

Mr. Farmer : Is he involved in this?

Mr. Tolson : Of course not, James.

(T/ PP/01:00:14,624)

The conversation above showed that Mr. Tolson depicted positive politeness strategy, i.e. being optimistic. Mr. Tolson was very optimistic that he was not with James at that night. The word of course showed sincerity hedge. He was not with James.

Dialogue 3

Mr. Tolson : You smell very good, Mr. Farmer.

James : Thank you, sir.

Mr. Tolson : You're very welcome.

(T/PP/00:10:35,781)

The conversation above showed that $\mathrm{Mr}$. Tolson revealed positive 
politeness strategy, i.e. giving compliment. In this case, Mr. Tolson gave a compliment to James because he smelt very good by saying "You smell very good, Mr. Farmer." Brown and Levinson (1987) clarify such a compliment as a sign of showing attention to the hearer's needs and wants. In other words, the compliment supported what James wanted to hear. It is in line with Wardaugh (2006, p. 277) that positive politeness leads to achieve solidarity through offers of friendship or the use of compliments. This strategy is commonly used by people who have already known each other fairly well like members of the same group or community.

Dialogue 4

James : Tolson's tough, isn't he?

Samantha : He sure is.

(J/PP/00:15:43,822)

The conversation above showed that James depicted positive politeness, i.e. seeking for an agreement. James thought $\mathrm{Mr}$. Tolson was a tough man. He used the question tag "is'nt he" with the question mark (?). He wanted Samantha to agree with him. The answer was either yes or no. In this case, Samantha agreed with him by answering "He sure is". As stated in Chapter II, Brown and Levinson (1987) state that another way to save positive face of a hearer is to seek ways in which it is possible to agree with him or her.

\section{Bald-on Record}

The characters in The Great Debaters movie revealed bald-on record politeness strategy. The subtypes of bald-on record politeness strategies used by the characters were task-oriented, great urgency, attention-getters, and greetings. The results and discussion of bald-on record politeness strategy were below as follows.

Dialogue 5

Mr. Tolson : I want you to come by my house tonight, 7:30. Corner of June and Campus.

Henry : :Why would I do that? (T/BOR 00:09:06,225)

The conversation above showed that Mr. Tolson revealed bald-onrecord politeness strategy, i.e. the use of task-oriented utterance. In this case, Mr. Tolson directly asked Henry to come by his house at 7.30. He gave Henry a task to fulfil. It is in line with Brown and Levinson (1987) that this strategy is used to give a task to a hearer in order to get the desire results. This subtype was the most dominant subtype revealed by the characters in the movie.

Dialogue 6

Henry : It's the school band,and they're outside.

Samantha : What? Jesus!

(S/BOR/01:05:11,053)

The conversation above showed that Samantha applied bald-onrecord politeness strategy, i.e. maximizing efficiency in an urgent situation (see Appendix A, p. 97, item 106). Bald-on record politeness strategy is applied because Samantha was shocked seeing what happened at 
that time. She used the words "what" and "Jesus" with raising intonation. It showed that she was in an urgent situation.

Dialogue 7

Mr. Tolson : Excuse me. We're waiting for you, Mr. Farmer.

James : I'm going, sir.

Mr. Tolson : Thank you, Mr. Farmer.

(T/BOR/00:10:30,710)

The conversation above showed that Mr. Tolson revealed bald-on record politeness strategy, i.e. attention getters. Mr. Tolson asked James to move quickly directly. However, the sentence "excuse me" was used to soften the request. Brown and Levinson (1987) assert that bald-on record strategy is employed as an attempt to minimize the efficiency of speaking. This subtype is trying to preserve face (instead of threatening it) which shows solidarity and respect to their communicative partners.

Dialogue 8

James : Good evening, Mr.

Tolson.

Mr. Tolson : Evening.

(J/BOR/00:10:28,574)

The dialogue above showed James applied bald-on record politeness strategy, i.e. greeting. In this case, James greeted Mr. Tolson to show his respect and to apologize for coming late. The word good evening is used to greet someone in the evening. It is in line with Brown and Levinson (1987) that this strategy is used when a speaker welcomes a hearer to show his or her friendliness or politeness.

\section{Off Record}

The characters of The Great Debaters movie revealed the subtype of off record politeness strategy, i.e. being incomplete, using metaphors, and using rhetorical questions. The results and discussion of off record politeness strategy were as follows.

Dialogue 9

Samantha : Most of the New Deal goes to children, anyway, and to the handicapped, and to old people--

Mr. Tolson : Is that fact, or conjecture?

(S/OR/00:12:56,755)

The dialogue above showed that Samantha depicted off-record politeness strategy, i.e. being incomplete. Samantha's utterance was incomplete. It left the implication of hanging in the air. She could not finish her utterance because Mr. Tolson interrupted her so she seemed confused about it. Brown and Levinson (1987) state that a speaker does not purposefully finish his or her utterance.

Dialogue 10

James : I don't know. I never really noticed.

Mr. Farmer : Because extracurricular activities like the debate team are fine, but you must not take your eye off the ball, son.

(F/OR/00:19:37,322)

The conversation above showed that Mr. Farmer applied off-record politeness strategy, i.e. using metaphor. In this case, Mr. Farmer gave advice to his son, James, by using metaphor. He made you must not take your eyes off the ball. He 
used the metaphor which had the same meaning as focus on something. He made James interpreted the meaning by himself. It is in line with Brown and Levinson (1987) that assert a speaker uses metaphor and makes a hearer interprets his or her intended meaning by him or herself.

Dialogue 11

James : Do you hear yourself? You sound like a kid!

Henry : Well, you are a kid!

(J/OR/01:38:45,799)

The conversation above showed that James used positive politeness strategy, i.e. using rhetorical questions. James, Samantha, and Henry fought about Gandhi for debate competition. James was angry. He said do you hear yourself? You sound like a kid!. He asked using rhetorical question with no intention of obtaining an answer. Based on Brown and Levinson (1987, p. 211), off-record or indirect strategy is done to let speakers figure out the unclear communication intention. Hence, the speakers could employ the strategy and let the hearers interpret the intention of the message to avoid the responsibility of doing FTAs.

\section{Negative Politeness}

The negative politeness strategy was the less dominant strategy applied by the characters in The Great Debaters movie. The characters revealed subtypes of negative politeness strategy, i.e. being pessimistic, being conventionally indirect, addressing terms as 'you' avoidance, and apologizing. The results and discussion of negative politeness strategy were as follows.

Dialogue 12

James : Mm-hmm. I guess I better go get me some punch.

Henry : Here, you can have mine if you want.

$(\mathrm{J} / \mathrm{NP} / 00: 30: 32,644)$

The dialogue above showed that James revealed off-record politeness strategy, i.e. being pessimistic. He made to express his doubt in making decision. He seemed confuse in making the reason. James made the utterance with low intonation. He directly expressed his pessimism to continue his activity before leaving her along with Henry. It is in line with Brown and Levinson (1987) that state this subtypes will give a compensation to a hearer's negative face by explicitly expressing doubt about the conditions of the appropriateness of a speaker's speech act obtain.

Dialogue 13

James : Can everybody shut up and go to bed?

Henry : James, come on, wake up.

(J/NP/01:41:43,944)

The dialogue above showed that James applied negative politeness strategy, i.e. being conventionally indirect. This strategy is conducted by using phrases and sentences that have contextually unambiguous meanings that are different from the literal meaning (Brown \& Levinson, 1987). Here, James asked Henry to shut up and go to bed for instance. 
To request Henry to shut up and go to bed, James used the words "can you shut up and go to bed?".

Dialogue 14

Henry : Mr. Tolson, it was a rough night.

Mr. Tolson : Yes, it was, $\mathrm{Mr}$. Lowe, for all of us.

(T/NP/01:28:34,355)

The conversation above showed that $\mathrm{Mr}$. Tolson revealed negative politeness strategy, i.e. the use of indirect address terms as 'you' avoidance. Mr. Tolson softened his utterance by using "you" avoidance. He mentioned $M r$. Lowe rather than you. It supports Brown and Levinson's (1987) statement that say another way of indicating that a speaker does not want to impinge on a hearer is to phrase the FTA as if the agents were other than the speaker or not the speaker alone at least and the hearer were other than the hearer or only inclusive of the hearer.

Dialogue 15

James : Sorry I'm late.

Mr. Farmer : You're sorry?

(J/NP/00:37:57,488)

The conversation above showed that James applied off-record politeness strategy, i.e. apologizing. He tried to beg forgiveness from his father for making his father worried that he came home late. He actually did not know his father was waiting for him. He apologized to his father in normal intonation. He wanted to respect him because he was his father. It was also to prevent conflict with his father after doing a mistake. It is in line with Brown and Levinson
(1987) that a speaker can indicate his or her reluctance to impinge on a hearer's negative face by apologizing for doing an FTA.

From the analysis of politeness strategies' utterances, the writer found the types of politeness strategies revealed by the characters in The Great Debaters movie were off record politeness strategy, bald-on record politeness strategy, positive politeness strategy, and negative politeness strategy.

\section{Factors Affecting the}

Characters' Politeness in Speaking

Language styles, registers and domains, slang and solidarity, and language and gender are factors that affect people in speaking politeness (Spolsky, 1998). In this research, the writer found the factors affecting the characters' politeness in speaking in The Great Debaters movie (see Appendix B) were language and styles, registers and domains, and slang and solidarity. The followings are the discussion of each factor.

\section{Language and Styles}

The movie contained some formal and informal expressions in the characters' utterances. Spolsky (1998) states that people can consciously choose how they try to use language by applying formal or informal expressions to people that they address. Further, Spolsky (1988) states that one's is likely to conform to the favored and educated norms of the society if the situation is more formal and he or she is giving more attention to the 
language. Simply put, language style refers to different degree of formality.

The characters' utterances in the movie contained formal and informal expressions. In a scene when James requested Henry to shut up, he said, "Can everybody shut up and go to bed?". The word "can" here represents formality instead of saying, "Shut up and go to bed". The six characters in the movie employed formal language style in speaking. The formal language style is considered as negative politeness strategy based on the theory of Brown and Levinson (1987).

\section{Registers and Domains}

A register is a variety of language most likely to be used in a specific situation and with particular roles and statuses involved (Spolsky, 1998). A register is marked by choices of vocabulary and of other aspects of styles. Besides, domain is named usually for a place or an activity. Spolsky (1998) states that register and domain belong to social situations which are also a key to determine politeness in speaking.

The conversations or the activities of the characters in the movie mostly took place in the campus. The topic of the conversation was mostly related to debate competition. Most of the time, the conversations took place in the classroom when Mr. Tolson was lecturing, explaining about debate. Mr. Tolson, James, Henry, Samantha, and Burgees talked about debate or debate competition. Their conversations would run such as "You know, there's never been a female on the debating team, ever" and "Tell me the irony in the name Bethlehem Steel Corporation" or "Harvard ain't going to debate us, not little old Wiley College in Marshall, Texas".

As a debate team, even outside of the campus, Mr. Tolson, James, Henry, Samantha, and Burgees, would engage in the conversations with the same topic, i.e. debate. The domain in the The Great Debaters movie was mostly college. Classroom, then, was the place. The role-relationship included a lecturer and students. Debate was the common topic of the conversation.

\section{Slang and Solidarity}

Slang is important in establishing a social identity. Spolsky (1998) states that slang is used as special kinds of intimate or in-group speech. Solidarity was represented by Samantha when she gave James a compliment about his presence in the debate team. She gave a compliment by saying, "You're our best researcher, James. We could not do this without you." It showed that she fully realized that James was giving a huge impact on their debate team even though he was only the researcher of the team.

By choosing the form of language associated with a specific group, the characters were making a claim to be counted as a member of the same group. The characters in The Great Debaters movie engaged in the same topic which was related 
to debate competition. Their conversations were mostly related to debate competition. Although $\mathrm{Mr}$. Tolson was a professor and a coach, there was no power connection in their relationship. They were still engaged in the same topic and situation. The tendency to use positive politeness strategies, emphasizing closeness between speaker and hearer, can be seen as slang and solidarity.

To sum up, it could be noticed that the types of politeness strategies and the factors affecting the characters' politeness were related. The characters of The Great Debaters movie were affected by three factors when they revealed the four types of politeness strategies.

\section{Conclusions and Suggestions}

The first research result showed that the types of politeness strategies used by the characters in The Great Debaters movie were off-record (indirect), bald-on-record (direct), positive politeness, and negative politeness. The second research result showed that the factors affecting the characters' politeness in speaking were language and styles, registers and domains, and slang and solidarity. However, the characters did not show language and gender factor in their conversation because they were mostly engaged in the same topic which was about debate competition.

The writer also gives suggestions for the following parties. First, for the English teachers, the writer hopes that the study will help teachers be more aware of the way they speak to others, especially when they teach in the classroom. They will be more prudent in selecting their words. Teacher can use positive politeness strategy such as "can you clean the whiteboard, please?" In addition, this study will encourage teachers to assess their students' proficiency in the sociolinguistic aspect, notably politeness.

Second, the writer hopes that the study will give some benefits to English language learners who study sociolinguistics and pragmatics. English language learners will understand the definition of politeness strategies and the factors affecting someone's politeness in speaking as those are elaborated in this study. Writer also hopes this study will help English language education learners apply their English proficiency appropriately in their teaching and learning practice. As a result, English language education learners will be able to speak English politely.

Third, the writer hopes the study will provide useful information related to politeness for its readers. Hopefully, it will enrich their knowledge and understanding of politeness. Readers will also understand the meaning of politeness itself, the politeness strategies, and the factors affecting people in speaking politely. Therefore, readers are able to apply politeness behavior in speaking with others.

Fourth, for future researchers, the writer expects the study will be a good reference for future researchers 
in conducting a research on information related to speaking pragmatics under the same topic. The study will also give valuable

politeness.

\section{References}

Brown, P., \& Levinson, S. C. (1987). Politeness: Some universals of language usage. Cambridge: Cambridge University Press.

Cohen, L., Manion, L., \& Morrison K. (2000). Research methods in education ( $^{\text {th }}$ ed.). London: Routledge Falmer.

Fraenkel, J. R., \& Wallen, N. E. (2006). How to design and evaluate research in education. Boston: McGraw-Hill.

Holmes, J. (1995). Women, men and politeness. London: Longman.

Potter, J., \& Wetherell, M. (2001). Unfolding discourse and social psychology. In M. Wetherell, S. Taylor, \& S. J. Yates (Eds.), Discourse theory and practice: A reader (pp. 198-209). London: Sage Publications

Spolsky, B. (1998). Sociolinguistics. Oxford: Oxford University Press.

Sutopo, H. B. (2002). Metodologi penelitian kualitatif. Surakarta: Sebelas Maret University Press.

Taylor, S. (2001). Locating and conducting discourse analytic research. In M. Wetherell, S. Taylor, \& S. J. Yates (Eds.), Discourse as a data: A guide for analysis (pp. 5-48). London: Sage Publications.

Willig, C. (2008). Introducing qualitative research in psychology. Berkshire: McGraw-Hill.

Yule, G. (1996). Pragmatics. Oxford: Oxford University Press. 